\title{
Comparative Analysis of Financial Performance Upon Automotive Companies Registered in BEI
}

\author{
Ninik Mas'adah ${ }^{1}$, Ira Megasyara ${ }^{2}$, Amrizal Imawan $^{3}$, Rizky Wahyudha Rosiawan ${ }^{4}$ \\ 1,2,3, Accounting Department, Faculty of Economics dan Business \\ Universitas Muhammadiyah Lamongan. \\ ${ }^{4}$ Management Department, Faculty of Economics dan Business \\ Universitas Muhammadiyah Lamongan. \\ * Corresponding author: \\ Email: ninikmasadah6@gmail.com
}

\begin{abstract}
.
This research was conducted to determine the financial performance of automotive companies listed on the IDX for the period 2012 to 2015. This type of research is a quantitative descriptive study, with a total population of 13 companies and a sample of 6 automotive companies that have been selected from the population with using purposive sampling method. The data analysis method used is a comparison method consisting of a cross sectional approach and time series analysis. The results show that the results of calculations using the cross-sectional approach, automotive companies in Indonesia for the 2012-2015 period experienced fluctuations and experienced a decline in the industry average at the end of 2015 and many automotive companies were in unhealthy condition in the 2012-2015 period. Based on the results of time series analysis of automotive companies in 2012-2015, it is known that the Total Assets Turn Over has decreased, the results on Net Profit Margin have decreased, the results on the current ratio have decreased, the result of the leverage ratio has increased. The management of automotive companies in Indonesia needs to increase investment in assets, because if the level of liquidity is high but the investment in assets is small, the money or cash available will only be stored and have less value for the company.
\end{abstract}

Keywords: automotive companies, Cross sectional aprroach, Time series analysi.

\section{INTRODUCTION}

The company as an organization has goals to be achieved to meet the interests of the company or the interests of its members. Success in achieving goals in the company is something that must be considered because the achievement of a goal is one of the achievements that can be achieved by the company and its management. Performance appraisal or performance appraisal of a company or organization can be used as a basis for decision making, both internal and external. The company's financial performance is a description of the company's financial condition which is analyzed with financial analysis tools, so that it can be seen about the good or bad financial condition of the company which is a reflection of the company's work performance during a certain period. 
This is an important matter so that the resources owned by the company can be used optimally in the face of environmental changes. In addition, performance appraisal is also used by management to fulfill their obligations to funders and to achieve the goals set by the company. The way to find out the good and bad finances of a company can be found by analyzing the relationships of various sectors in the financial statements. Some of the analytical tools used in measuring financial performance in a company include liquidity ratios, solvency, profitability, activity and market ratios. Analysis using ratios is a common thing, where the results can provide a relative measure of the company's operations [1,2].

The ratio analysis is sourced from the company's financial statements, from which sources can be seen the development of the company's financial performance from year to year and can take preventive actions to avoid business failure. The financial analysis itself starts with using basic finance, namely balance sheet, profit and loss calculation and cash flow statement. Financial ratios and company performance have a close relationship, financial ratios have a large number and each ratio has its own use. For investors, the ratio used must present the purpose of the analysis being carried out, if the ratio is not in accordance with the analysis carried out, then the ratio will not be used for that investor.

For internal companies, financial ratio analysis is one way to find out the extent of the company's financial performance which can then directly improve or improve financial performance if it produces ratios that are not in accordance with the company's targets, so that the company can continue to compete in an increasingly competitive market [3]. Analyzing financial performance, a financial analyst will be able to assess whether the financial manager can plan and implement into every action consistently with the aim of maximizing shareholder prosperity. This kind of analysis can also be used by other parties, such as banks, to assess whether it is reasonable (feasible) to provide additional funds or new credit.

Prospective investors to project the company's future prospects. Indonesia is one of the countries with a large population, so many Multi National Corporate (MNC) companies are looking to Indonesia as a profitable market. One industry that shows rapid development in Indonesia is the automotive industry. The number of motorized vehicles, both cars and motorbikes, is increasingly filling the roads in Indonesia. This is what makes many automotive manufacturers, both local and international, compete to become the number one producer in Indonesia. The development of the automotive world over the last few years has made manufacturers have to consider things that can make financial performance in a positive trend, so that they can continue to compete in the market. This factor makes many researchers want to reveal the financial performance of various industrial sectors, as has been done [4, 5]. During the last four years, car sales in Indonesia have experienced ups and downs, where car retail in Indonesia has reached four hundred thousand. The Indonesian Automotive Industry (Gaikindo) in the form of data on the growth of the automotive market in Indonesia 
from 2012 to 2015. Data shows that the growth of the automotive market in Indonesia increased rapidly in 2013, then decreased in 2014 and 2015. In contrast to other factories, Honda's factory in fact experienced a market increase from year to year. The retail amount is the number of sales each year, while the market percentage is the total control of the automotive market in Indonesia.

This decline was caused by many factors, one of the factors being the sluggish automotive market in 2014 due to the sluggish global economy, a senior economist [6] revealed that the automotive industry was only one of the factors affected by this global economic downturn. "If you reflect on the previous year, the growth of the automotive industry today (2015) is not as big as in 2012." Even in 2015, car sales fell $7 \%$ from the previous year. However, that does not mean there is no potential" (http://fokus.kontan.co.id). The slowdown in the global economy also resulted in the shutdown of one of the factories originating from America, namely the Ford Motor Company, after nearly 27 years in Indonesia, Ford, which is the largest factory in America, closed its operations in 2016.

\section{LITERATURE REVIEW}

The company's financial performance can be interpreted as a result of one's efforts achieved by the ability and actions in certain situations [7]. Performance is a measure of achievement in carrying out tasks based on the level of ability that can be done, thus performance is the relationship between effort, ability and task perception. Company performance is a company display in a certain period. Company performance appraisal is the periodic determination of the operational effectiveness of an organization, employees based on predetermined standard and performance goals [8]. Measurement of company performance that is commonly used is a measurement of the level of liquidity, activity, solvency and profitability as follows:

Liquidity Ratio in measuring the ability of a company to meet its short-term liabilities, where the liquidity ratio identifies the relationship between current assets and current liabilities. Current ratio is the ratio between current assets and current debt. Current assets consist of cash, marketable securities, accounts receivable and inventories. Meanwhile, current debt consists of accounts payable, notes payable, tax payable, salary / wages payable, and other short-term debts. A high current ratio indicates a good guarantee for creditors, meaning that at any time the company has the ability to pay off its short-term obligations. Conversely, a low current ratio indicates bad collateral for creditors, meaning that the company is unable to pay off its shortterm obligations. The formula used.

$$
\text { Current Ratto }=\frac{\text { Aktlva Lancar }}{\text { Hutomg Lancor }} x 100 \%
$$

The quick ratio is the ratio of the reduction between total current assets minus inventories divided by current debt. Quick ratio focuses more on the components of 
current assets that are more liquid, namely: cash, marketable securities, and receivables that are linked to current debt. Whereas inventory is the most illiquid element of current assets and the asset element is often a loss in the event of liquidity, with the formula for use, namely:

\section{Qutck Batto $=\frac{\text { Aktva Lancar }- \text { Persedtan }}{\text { Hutang Lancar }} \times 100 \%$}

Activity Ratio, activity ratio is a ratio that measures how efficient a company is in managing its assets and utilizing the resources it owns. This is also expressed [9]. Activity ratio is a ratio that measures how a company uses its assets. Leverage Ratio (Solvency). The activity ratios used in this study consisted of:

Receivable Turn Over dengan rumus:

$$
\text { Recelvable Twn Over }=\frac{\text { Penfualan Kredtt Bersth }}{\text { Rata }- \text { rata Plutang }} \times 1
$$

Inventory Turn Over

$$
\text { Inventory Turn Over }=\frac{\text { Haroa Pokok Penhalan }}{\text { Rata }- \text { rata Persedtaan }} x 1
$$

Total Assets Turn Over

$$
\text { Total Assets Twn Over }=\frac{\text { Pen/ualan Bersth }}{\text { Total Ahtlva }} \times 1
$$

Leverage ratio (solvency) is a ratio that measures a company's ability to meet its long-term obligations. [10] the leverage ratio is a ratio that measures how far a company uses its total debt.

Debt to Assets Ratio

Debt to Equity Ratio

$$
\text { Debt to Assets Rotto }=\frac{\text { Total Hutang }}{\text { Total Aktlva }} \times 100 \%
$$

$$
\text { Debt to Equity Ratlo }=\frac{\text { Total Hutang }}{\text { MadaL Sendivt }} \times 100 \%
$$

Profitability ratio, profitability ratio is a ratio that measures the company's ability to generate profits during a certain period and also provides an overview of the level of management effectiveness in carrying out its operational activities. Profitability also has a positive relationship with the dividend payout ratio, because the higher the level of profitability, the greater the dividends distributed by the company to investors [11]. The profitability ratios used in the study consist of:

Gross Profit Margin

Gross Proft Margh

$$
=\frac{\text { Penjulan Bersth }- \text { Harga Pokok Penjulan }}{\text { Penfualan Bersth }} \times 100 \%
$$

Net Profit Margin 


$$
\text { Net Proft Margh }=\frac{\text { Laba Bersih Setelah Pajak }}{\text { Penpalan Bersih }} x 100 \%
$$

Return on Assets

$$
\text { Return On Assets }=\frac{\text { Laba Sebelum Pajak (EBIT) }}{\text { Total Aktlva }} \times 100 \%
$$

Return on Equity

\section{Hypothesis Development}

$$
\text { Return } O_{n} \text { Equity }=\frac{\text { Laba Bersth Setelah Pajak }}{\text { Total Modal Sendivi }} \times 100 \%
$$

This study focuses on the performance of automotive companies listed on the IDX for the period 2012-2015 as seen from the main financial statements, namely balance sheets and profit (loss) statements in a certain period, in the assessment used four analytical tools, namely; the liquidity ratio which includes the current ratio, then the next analysis is financial leverage which consists of total debt ratio, the next analysis is the activity ratio consisting of total debt assets and finally the profitability ratio consisting of net profit margin.

$\mathrm{H}_{1}$ : Comparison of automotive financial performance in an increasing period.

\section{METHODS}

The research design is a quantitative descriptive study, namely research which describes and describes a particular situation which provides an overview of the state of a variable that is in accordance with the reality of the study. [12]. The population in this study are all automotive companies listed on the IDX, in this case the data is sourced from the company's financial statement documents which include the balance sheet and profit (loss) statements for the period 2013-2015. The sample is from one population and uses the company's financial statements which include the balance sheet and profit (loss) statements for the period 2013-2015, with a purposive sampling method where the sample is selected based on certain criteria. The technique of data collection and data analysis uses an Annual Report which is listed on the Indonesia Stock Exchange, while the data analysis uses comparative analysis, namely time series analysis and cross-sectional approach as well as performance appraisal by looking at the activity ratio, profitability ratio, liquidity ratio and leverage.

\section{RESULT AND DISCUSSION}

Result

The results of time series analysis were carried out by comparing the financial performance ratios of automotive companies listed on the Indonesia Stock Exchange (IDX) and selected as samples in 2012 - 2015. The results of the liquidity ratios in 2012-2015 in automotive companies can be seen in the table below. 
Table 1. Automotive Company Liquidity Ratio $2012-2015$

\begin{tabular}{|c|c|c|c|c|}
\hline \multirow{2}{*}{ Company Code } & \multicolumn{4}{|c|}{ Current Ratio } \\
\hline & 2012 & 2013 & Difference & Information \\
\hline ASII & $1,40 \%$ & $1,24 \%$ & $-0,16 \%$ & Decreased \\
\hline AUTO & $1,16 \%$ & $1,84 \%$ & $0,68 \%$ & Increased \\
\hline BRAM & $2,13 \%$ & $1,57 \%$ & $-0,56 \%$ & Decreased \\
\hline INDS & $2,33 \%$ & $3,86 \%$ & $1,53 \%$ & Increased \\
\hline NIPS & $1,11 \%$ & $1,05 \%$ & $-0,06 \%$ & Decreased \\
\hline SMSM & $2,05 \%$ & $2,11 \%$ & $0,06 \%$ & Increased \\
\hline \multirow{2}{*}{ Company Code } & \multicolumn{4}{|c|}{ Current Ratio } \\
\hline & 2013 & 2014 & Difference & Information \\
\hline ASII & $1,24 \%$ & $1,31 \%$ & $0,07 \%$ & Increased \\
\hline AUTO & $1,84 \%$ & $1,33 \%$ & $-0,51 \%$ & Decreased \\
\hline BRAM & $1,57 \%$ & $1,42 \%$ & $-0,15 \%$ & Decreased \\
\hline INDS & $3,86 \%$ & $2,91 \%$ & $-0,95 \%$ & Decreased \\
\hline NIPS & $1,05 \%$ & $1,29 \%$ & $0,24 \%$ & Increased \\
\hline SMSM & $2,11 \%$ & $2,11 \%$ & $0 \%$ & Constan \\
\hline \multirow{2}{*}{ Company Code } & \multicolumn{4}{|c|}{ Current Ratio } \\
\hline & 2014 & 2015 & Difference & Information \\
\hline ASII & $1,31 \%$ & $1,38 \%$ & $0,07 \%$ & Increased \\
\hline AUTO & $1,33 \%$ & $1,32 \%$ & $-0,01 \%$ & Decreased \\
\hline BRAM & $1,42 \%$ & $1,81 \%$ & $0,39 \%$ & Increased \\
\hline INDS & $2,91 \%$ & $2,23 \%$ & $-0,68 \%$ & Decreased \\
\hline NIPS & $1,29 \%$ & $1,05 \%$ & $-0,24 \%$ & Decreased \\
\hline SMSM & $2,11 \%$ & $2,39 \%$ & $0,28 \%$ & Increased \\
\hline
\end{tabular}

Source: Process data

The results of the liquidity ratio of automotive companies in 2012-2013 experienced an increase in four companies and the remaining companies, namely Astra International and Nipress, experienced a decline. In 2013-2014 the Astra International and Nipress companies experienced an increase and Selamat Sempurna received constant value, while the other three companies experienced a decline. From 2014 to 2015, Astra International was still experiencing an increase and Indo Kordsa and Selamat Sempurna also experienced an increase in 2014-2015. Meanwhile, three companies experienced a decline, namely Nipress, Astra Otoparts and Indospring. Overall, the condition of financial performance in Indonesia is in an unhealthy condition where the liquidity ratio of automotive companies is below $2 \%$ [13]. This result is reinforced [14] which states that companies that experience ups and downs of these assets will have an impact on their financial and income development. Based on these results, it can be concluded that every year many companies show a decrease in the company's ability to pay off short-term obligations, this is evident from the ups and downs in the company so that this situation is not good for the company. The next is the results of the activity ratios for 2012 - 2015 at automotive companies can be seen in the table below. 
Table 2. Automotive Company Activity Ratios Period 2012 - 2013

\begin{tabular}{lcccc}
\hline \multirow{2}{*}{ Company Code } & \multicolumn{4}{c}{ Total Assets Turnover } \\
\cline { 2 - 5 } & $\mathbf{2 0 1 2}$ & $\mathbf{2 0 1 3}$ & Difference & Information \\
\hline ASII & 1,03 & 0,91 & $-0,12$ & Decreased \\
\hline AUTO & 0,93 & 0,86 & $-0,07$ & Decreased \\
\hline BRAM & 0,76 & 0,84 & 0,08 & Increased \\
\hline INDS & 0,89 & 0,78 & $-0,11$ & Decreased \\
\hline NIPS & 1,34 & 1,14 & $-0,2$ & Decreased \\
\hline SMSM & 1,51 & 1,39 & $-0,12$ & Decreased \\
\hline SOIF
\end{tabular}

Source: Process data

Table 3. Automotive Company Activity Ratio 2013 - 2015

\begin{tabular}{lcccc}
\hline \multicolumn{1}{c}{ Company Code } & \multicolumn{4}{c}{ Total Assets Turnover } \\
\cline { 2 - 5 } & $\mathbf{2 0 1 3}$ & $\mathbf{2 0 1 4}$ & Difference & Information \\
\hline ASII & 0,91 & 0,85 & $-0,06$ & Decreased \\
\hline AUTO & 0,86 & 0,85 & $-0,01$ & Decreased \\
\hline BRAM & 0,84 & 0,67 & $-0,17$ & Decreased \\
\hline INDS & 0,78 & 0,82 & 0,04 & Increased \\
\hline NIPS & 1,14 & 0,84 & $-0,3$ & Decreased \\
\hline SMSM & 1,39 & 1,51 & 0,12 & Increased \\
\hline
\end{tabular}

Source: Process data

Tabel 4. Automotive Company Activity Ratio 2014 - 2015

\begin{tabular}{lcccc}
\hline \multirow{2}{*}{ Company Code } & \multicolumn{5}{c}{ Total Assets Turnover } \\
\cline { 2 - 5 } & $\mathbf{2 0 1 4}$ & $\mathbf{2 0 1 5}$ & Difference & Information \\
\hline ASII & 0,85 & 0,75 & $-0,1$ & Decreased \\
\hline AUTO & 0,85 & 0,82 & $-0,03$ & Decreased \\
\hline BRAM & 0,67 & 0,71 & 0,04 & Increased \\
\hline INDS & 0,82 & 0,65 & $-0,17$ & Decreased \\
\hline NIPS & 0,84 & 0,64 & $-0,2$ & Decreased \\
\hline SMSM & 1,51 & 1,26 & $-0,25$ & Decreased \\
\hline
\end{tabular}

Source: Process data

The total asset turnover of the automotive company was not in a healthy condition, because in 2012 - 2013 the company that experienced an increase in total asset turnover was only PT. Indo Kordsa with an increase of 0.08 and all companies decreased. From 2013 to 2014 there were 2 companies that experienced an increase, namely PT. Indospring (0.04) and PT. Selamat Sempurna $(1,2)$ and all companies experienced a decrease in total asset turnover. From 2014 - 2015, companies that experienced an increase were PT. Indo Kordsa with an increase of 0.04 and all companies experiencing a decrease in total asset turnover, the overall financial performance of automotive companies in Indonesia is in an unhealthy state because the average value each year is less than 2x (Houston, 2010, p. 139). This shows that automotive companies in Indonesia have not been able to maximize the total assets owned in order to increase the resulting business income and the total income is less than the total value of assets owned by the company. 
The results of the solvency ratio for 2012 - 2015 in automotive companies can be seen in the following table:

Tabel 5. Automotive Company Profitability Ratio 2012 - 2015

\begin{tabular}{lcccc}
\hline \multirow{2}{*}{ Company Code } & \multicolumn{4}{c}{ Net Profit Margin } \\
\cline { 2 - 5 } & $\mathbf{2 0 1 2}$ & $\mathbf{2 0 1 3}$ & Difference & Information \\
\hline ASII & $12,1 \%$ & $11,5 \%$ & $-0,6 \%$ & Decreased \\
\hline AUTO & $13,7 \%$ & $9,3 \%$ & $-4,4 \%$ & Decreased \\
\hline BRAM & $12,9 \%$ & $2,5 \%$ & $-9,4 \%$ & Decreased \\
\hline INDS & $9,1 \%$ & $8,7 \%$ & $-0,4 \%$ & Decreased \\
\hline NIPS & $3,1 \%$ & $3,7 \%$ & $0,6 \%$ & Increased \\
\hline SMSM & $11 \%$ & $14 \%$ & $3 \%$ & Increased \\
\hline \multicolumn{1}{c}{ Company Code } & \multicolumn{4}{c}{ Net Profit Margin } \\
\hline ASII & $\mathbf{2 0 1 3}$ & $\mathbf{2 0 1 4}$ & Selisih & Keterangan \\
\hline AUTO & $11,5 \%$ & $11,0 \%$ & $-0,5 \%$ & Decreased \\
\hline BRAM & $9,3 \%$ & $7,8 \%$ & $-0,5 \%$ & Decreased \\
\hline INDS & $2,5 \%$ & $7,9 \%$ & $5,4 \%$ & Increased \\
\hline NIPS & $8,7 \%$ & $6,8 \%$ & $-1,9 \%$ & Decreased \\
\hline SMSM & $3,7 \%$ & $4,9 \%$ & $1,2 \%$ & Increased \\
\hline \multicolumn{1}{c}{ Company Code } & $14 \%$ & $16 \%$ & $2 \%$ & Increased \\
\hline ASII & $\mathbf{2 0 1 4}$ & $\mathbf{2 0 1 5}$ & Net Profit Margin & \\
\hline AUTO & $11,0 \%$ & $8,5 \%$ & $-2,5 \%$ & Decreased \\
\hline BRAM & $7,8 \%$ & $2,8 \%$ & $-5 \%$ & Decreased \\
\hline INDS & $7,9 \%$ & $6 \%$ & $-1,9 \%$ & Decreased \\
\hline NIPS & $6,8 \%$ & $0,1 \%$ & $-6,7 \%$ & Decreased \\
\hline SMSM & $4,9 \%$ & $3,1 \%$ & $-1,8 \%$ & Decreased \\
\hline SOurce $:$ Pronce & Information \\
\hline
\end{tabular}

Source: Process data

Based on the table above, the automotive companies' net profit margins show that many companies have experienced a decline, while those that experienced an increase in 2012 - 2013 were only Nipress and Selamat Sempurna. In 2013 - 2014, companies that experienced a decrease in net profit margins were Astra International, Astra Otoparts, and Indosping. Furthermore, Nipress, Selamat Sempurna and Indo Kordsa experienced an increase in net profit margins. The results in 2014 - 2015 of all automotive in Indonesia experienced a decline, but Selamat Sempurna produced constant net profit margins. The overall results show that automotive companies in Indonesia are in an unhealthy condition because they are below 5\% [15]. This indicates a decline in the company's financial performance, resulting in a decrease in net income generated by the company. This result is supported by the research [16] explaining that the profitability ratio does not provide significant results in financial reports, thus producing negative results in financial reports.

The results of the cross-sectional analysis calculation will make a comparison of the financial performance ratios of automotive companies listed on the Indonesia Stock Exchange (IDX) in 2012 - 2015 with the average in the industry. The results of crosssectional analysis of liquidity ratios can be seen in the table below. 
International Journal Of Science, Technology \& Management

Table 6. Results of the Liquidity Ratio of Automotive Companies 2012 - 2015

\begin{tabular}{|c|c|c|c|c|c|}
\hline \multirow{2}{*}{$\begin{array}{c}\text { Company } \\
\text { Code }\end{array}$} & \multicolumn{4}{|c|}{2012} & \multirow[b]{2}{*}{ Decision } \\
\hline & $\begin{array}{c}\text { Current } \\
\text { Ratio }\end{array}$ & $\begin{array}{c}\text { Mean } \\
\text { Industry }\end{array}$ & Difference & Information & \\
\hline ASII & $1,40 \%$ & $1,70 \%$ & $0,30 \%$ & $<$ rr industry & Unhealthy \\
\hline AUTO & $1,16 \%$ & $1,70 \%$ & $0,54 \%$ & $<$ rr industry & Unhealthy \\
\hline BRAM & $2,13 \%$ & $1,70 \%$ & $-0,96 \%$ & $<$ rr industry & Unhealthy \\
\hline INDS & $2,33 \%$ & $1,70 \%$ & $-0,63 \%$ & $<$ rr industry & Unhealthy \\
\hline NIPS & $1,11 \%$ & $1,70 \%$ & $0,59 \%$ & $>$ rr industry & Healthy \\
\hline SMSM & $2,05 \%$ & $1,70 \%$ & $-0,35 \%$ & $>$ rr industry & Healthy \\
\hline \multicolumn{6}{|c|}{2013} \\
\hline ASII & $1,24 \%$ & $1,95 \%$ & $0,71 \%$ & $<$ rr industry & Unhealthy \\
\hline AUTO & $1,84 \%$ & $1,95 \%$ & $0,1 \%$ & $<$ rr industry & Unhealthy \\
\hline BRAM & $1,57 \%$ & $1,95 \%$ & $0,38 \%$ & $<$ rr industry & Unhealthy \\
\hline INDS & $3,86 \%$ & $1,95 \%$ & $-1,91 \%$ & $<$ rr industry & Unhealthy \\
\hline NIPS & $1,05 \%$ & $1,95 \%$ & $0,9 \%$ & $>$ rr industry & Healthy \\
\hline SMSM & $2,11 \%$ & $1,95 \%$ & $-0,16 \%$ & $>$ rr industry & Healthy \\
\hline \multicolumn{6}{|c|}{2014} \\
\hline ASII & $1,31 \%$ & $1,73 \%$ & $0,42 \%$ & $<$ rr industry & Unhealthy \\
\hline AUTO & $1,33 \%$ & $1,73 \%$ & $0,4 \%$ & $<$ rr industry & Unhealthy \\
\hline BRAM & $1,42 \%$ & $1,73 \%$ & $0,31 \%$ & $<$ rr industry & Unhealthy \\
\hline INDS & $2,91 \%$ & $1,73 \%$ & $-1,18 \%$ & $<$ rr industry & Unhealthy \\
\hline NIPS & $1,29 \%$ & $1,73 \%$ & $0,44 \%$ & $<$ rr industry & Unhealthy \\
\hline SMSM & $2,11 \%$ & $1,73 \%$ & $-0,38 \%$ & $>$ rr industry & Healthy \\
\hline
\end{tabular}

Source: Process data

Table 7. Analysis of the Liquidity Ratio of Automotive Companies 2012 - 2015

2015

\begin{tabular}{lccccc}
\multicolumn{1}{c}{$\begin{array}{c}\text { Company } \\
\text { Code }\end{array}$} & $\begin{array}{c}\text { Current } \\
\text { Ratio }\end{array}$ & $\begin{array}{c}\text { Mean } \\
\text { Industry }\end{array}$ & Difference & Information & Decision \\
\hline ASII & $1,38 \%$ & $1,70 \%$ & $0,32 \%$ & $<$ rr industry & Unhealthy \\
\hline AUTO & $1,32 \%$ & $1,70 \%$ & $0,38 \%$ & $<$ rr industry & Unhealthy \\
\hline BRAM & $1,81 \%$ & $1,70 \%$ & $-0,11 \%$ & $<$ rr industry & Unhealthy \\
\hline INDS & $2,23 \%$ & $1,70 \%$ & $-0,53 \%$ & $<$ rr industry & Unhealthy \\
\hline NIPS & $1,05 \%$ & $1,70 \%$ & $0,65 \%$ & $<$ rr industry & Unhealthy \\
\hline SMSM & $2,39 \%$ & $1,70 \%$ & $-0,69 \%$ & $>$ rr industry & Healthy \\
\hline
\end{tabular}

Source: Process data

It can be seen that in 2012 - 2015 when viewed from the Current Ratio the average automotive company industry in Indonesia experienced a decline until the end of 2015 with an industry average value of $1.70 \%$. The next results show that in the 2012 - 2015 period, many companies were categorized as unhealthy because the ratio owned by the company was below the industry average. Companies that fall into the healthy category are only PT. Nipress in 2012 - 2013 while in 2014 - 2015 PT. Nipress 
International Journal Of Science, Technology \& Management

is also in the unhealthy category. Companies that remain in the healthy category are only PT. Selamat Sempurna in 2012 - 2015, while other companies were in the unhealthy category from 2012-2015. Then the results of the activity ratio analysis can be seen in the following table:

Table 8. Analysis of Automotive Company Activity Ratio 2012 - 2013.

\begin{tabular}{|c|c|c|c|c|c|}
\hline \multirow{2}{*}{$\begin{array}{l}\text { Company } \\
\text { Code }\end{array}$} & \multicolumn{4}{|c|}{2012} & \multirow[t]{2}{*}{ Decision } \\
\hline & $\begin{array}{c}\text { Total Assets } \\
\text { Turnover }\end{array}$ & $\begin{array}{c}\text { Mean } \\
\text { Industry }\end{array}$ & Difference & Information & \\
\hline ASII & 1,03 & 1,07 & $0,04 \%$ & $<$ rr industry & Unhealthy \\
\hline AUTO & 0,93 & 1,07 & $0,14 \%$ & $<$ rr industry & Unhealthy \\
\hline BRAM & 0,76 & 1,07 & $0,31 \%$ & $<$ rr industry & Unhealthy \\
\hline INDS & 0,89 & 1,07 & $0,18 \%$ & $<$ rr industry & Unhealthy \\
\hline NIPS & 1,34 & 1,07 & $-0,27 \%$ & $>$ rr industry & Healthy \\
\hline SMSM & 1,51 & 1,07 & $-0,44 \%$ & $>$ rr industry & Healthy \\
\hline \multicolumn{6}{|c|}{2013} \\
\hline ASII & 0,91 & 0,98 & 0,07 & $<$ rr industry & Unhealthy \\
\hline AUTO & 0,86 & 0,98 & 0,12 & $<$ rr industry & Unhealthy \\
\hline BRAM & 0,84 & 0,98 & 0,14 & $<$ rr industry & Unhealthy \\
\hline INDS & 0,78 & 0,98 & 0,2 & $<$ rr industry & Unhealthy \\
\hline NIPS & 1,14 & 0,98 & $-0,16$ & $>$ rr industry & Healthy \\
\hline SMSM & 1,39 & 0,98 & $-0,41$ & $>$ rr industry & Healthy \\
\hline
\end{tabular}

Source: Process data

Tabel 9. Automotive Company Analysis 2014 - 2015

\begin{tabular}{|c|c|c|c|c|c|}
\hline \multirow[b]{2}{*}{$\begin{array}{l}\text { Company } \\
\text { Code }\end{array}$} & \multicolumn{4}{|c|}{2014} & \multirow[b]{2}{*}{ Decision } \\
\hline & $\begin{array}{c}\text { Total Assets } \\
\text { Turnover }\end{array}$ & $\begin{array}{c}\text { Mean } \\
\text { Industry }\end{array}$ & Difference & Information & \\
\hline ASII & 0,85 & 0,92 & 0,07 & $<$ rr industry & Unhealthy \\
\hline AUTO & 0,85 & 0,92 & 0,07 & $<$ rr industry & Unhealthy \\
\hline BRAM & 0,67 & 0,92 & 0,25 & $<$ rr industry & Unhealthy \\
\hline INDS & 0,82 & 0,92 & 0,1 & $<$ rr industry & Unhealthy \\
\hline NIPS & 0,84 & 0,92 & 0,08 & $<$ rr industry & Unhealthy \\
\hline SMSM & 1,51 & 0,92 & $-0,59$ & $>$ rr industry & Healthy \\
\hline \multicolumn{6}{|c|}{2015} \\
\hline ASII & 0,75 & 0,81 & 0,06 & $<$ rr industry & Unhealthy \\
\hline AUTO & 0,82 & 0,81 & 0,01 & $>$ rr industry & Healthy \\
\hline BRAM & 0,71 & 0,81 & 0,1 & $<$ rr industry & Unhealthy \\
\hline INDS & 0,65 & 0,81 & 0,16 & $<$ rr industry & Unhealthy \\
\hline NIPS & 0,64 & 0,81 & 0,17 & $<$ rr industry & Unhealthy \\
\hline SMSM & 1,26 & 0,81 & $-0,45$ & $>$ rr industry & Healthy \\
\hline
\end{tabular}

Source: Process data

Based on the results in 2012 - 2015, when viewed from the total asset turnover, the average automotive company industry in Indonesia has decreased until the end of 
2015 with an average value of 0.81 . The next results show that in the $2012-2015$ period, many companies were categorized as unhealthy because the ratio owned by the company was below the industry average. Companies that fall into the healthy category are only PT. Nipress in 2012 - 2013 while in 2014 - 2015 PT. Nipress is also in the unhealthy category. Companies that remain in the healthy category are only PT. Selamat Sempurna in 2012 - 2015, while other companies were in the unhealthy category from 2012-2015. The results of the leverage ratio analysis can be seen in the following table:

Table 10. Results of Automotive Company Leverage Ratio Analysis 2012 - 2015

\begin{tabular}{|c|c|c|c|c|c|}
\hline \multirow[b]{2}{*}{$\begin{array}{l}\text { Company } \\
\text { Code }\end{array}$} & \multicolumn{4}{|c|}{2012} & \multirow[b]{2}{*}{ Decision } \\
\hline & Debt Ratio & $\begin{array}{c}\text { Mean } \\
\text { Industry }\end{array}$ & Difference & Information & \\
\hline ASII & $0,51 \%$ & 0,41 & $-0,1 \%$ & $>$ rr industry & Healthy \\
\hline AUTO & $0,36 \%$ & 0,41 & $0,05 \%$ & $<$ rr industry & Unhealthy \\
\hline BRAM & $0,26 \%$ & 0,41 & $0,15 \%$ & $<$ rr industry & Unhealthy \\
\hline INDS & $0,32 \%$ & 0,41 & $0,09 \%$ & $<$ rr industry & Unhealthy \\
\hline NIPS & $0,61 \%$ & 0,41 & $-0,2 \%$ & $>$ rr industry & Healthy \\
\hline SMSM & $0,42 \%$ & 0,41 & $-0,01 \%$ & $>$ rr industry & Healthy \\
\hline \multicolumn{6}{|c|}{2013} \\
\hline ASII & $0,50 \%$ & 0,41 & $-0,09 \%$ & $>$ rr industry & Healthy \\
\hline AUTO & $0,25 \%$ & 0,41 & $0,16 \%$ & $<$ rr industry & Unhealthy \\
\hline BRAM & $0,32 \%$ & 0,41 & $0,09 \%$ & $<$ rr industry & Unhealthy \\
\hline INDS & $0,20 \%$ & 0,41 & $0,21 \%$ & $<$ rr industry & Unhealthy \\
\hline NIPS & $0,71 \%$ & 0,41 & $-0,3 \%$ & $>$ rr industry & Healthy \\
\hline SMSM & $0,41 \%$ & 0,41 & $0 \%$ & $>$ rr industry & Healthy \\
\hline \multicolumn{6}{|c|}{2014} \\
\hline ASII & $0,5 \%$ & 0,38 & $-0,12 \%$ & $>$ rr industry & Healthy \\
\hline AUTO & $0,30 \%$ & 0,38 & $0,08 \%$ & $<$ rr industry & Unhealthy \\
\hline BRAM & $0,42 \%$ & 0,38 & $-0,16 \%$ & $>$ rr industry & Healthy \\
\hline INDS & $0,20 \%$ & 0,38 & $0,18 \%$ & $<$ rr industry & Unhealthy \\
\hline NIPS & $0,52 \%$ & 0,38 & $-0,26 \%$ & $>$ rr industry & Healthy \\
\hline SMSM & $0,34 \%$ & 0,38 & $0,04 \%$ & $<$ rr industry & Unhealthy \\
\hline \multicolumn{6}{|c|}{2015} \\
\hline ASII & $0,4 \%$ & 0,38 & $-0,02 \%$ & $>$ rr industry & Healthy \\
\hline AUTO & $0,29 \%$ & 0,38 & $0,09 \%$ & $<$ rr industry & Unhealthy \\
\hline BRAM & $0,37 \%$ & 0,38 & $0,01 \%$ & $<$ rr industry & Unhealthy \\
\hline INDS & $0,25 \%$ & 0,38 & $0,13 \%$ & $<$ rr industry & Unhealthy \\
\hline NIPS & $0,61 \%$ & 0,38 & $-0,23 \%$ & $>$ rr industry & Healthy \\
\hline SMSM & $0,35 \%$ & 0,38 & $0,03 \%$ & $<$ rr industry & Unhealthy \\
\hline
\end{tabular}

Source: Process data

The average Debt Ratio of the automotive company industry in Indonesia decreased until the end of 2015 with an average value of $0.38 \%$ from the industry 
average value of $0.41 \%$ in 2014 . The following results show that in the period 2012 2015 there were many companies which is included in the unhealthy category because the ratio owned by the company is below the industry average. Companies that fall into the healthy category are only PT. Nipress and PT. Happy Perfect in 2012 - 2013 while in 2014 - 2015 PT. Congratulations Perfect is also in the unhealthy category.

Table 11. Automotive Company Profitability Ratio Analysis 2012 - 2013

2012

\begin{tabular}{|c|c|c|c|c|c|}
\hline \multirow[b]{2}{*}{ Company Code } & \multicolumn{4}{|c|}{2012} & \multirow[b]{2}{*}{ Decision } \\
\hline & ROA & $\begin{array}{c}\text { Mean } \\
\text { Industry }\end{array}$ & Difference & Information & \\
\hline ASII & $19,9 \%$ & $20,1 \%$ & $0,2 \%$ & $<$ rr industry & Unhealthy \\
\hline AUTO & $15,3 \%$ & $20,1 \%$ & $4,8 \%$ & $<$ rr industry & Unhealthy \\
\hline BRAM & $6,3 \%$ & $20,1 \%$ & $13,8 \%$ & $<$ rr industry & Unhealthy \\
\hline INDS & $17,7 \%$ & $20,1 \%$ & $2,4 \%$ & $<$ rr industry & Unhealthy \\
\hline NIPS & $22,7 \%$ & $20,1 \%$ & $-2,6 \%$ & $>$ rr industry & Healthy \\
\hline SMSM & $38,6 \%$ & $20,1 \%$ & $-18,5 \%$ & $>$ rr industry & Healthy \\
\hline \multicolumn{6}{|c|}{2013} \\
\hline ASII & $16,5 \%$ & $18,5 \%$ & $2 \%$ & $<$ rr industry & Unhealthy \\
\hline AUTO & $13,2 \%$ & $18,5 \%$ & $5,3 \%$ & $<$ rr industry & Unhealthy \\
\hline BRAM & $9,3 \%$ & $18,5 \%$ & $9,2 \%$ & $<$ rr industry & Unhealthy \\
\hline INDS & $14,8 \%$ & $18,5 \%$ & $3,7 \%$ & $<$ rr industry & Unhealthy \\
\hline NIPS & $19,2 \%$ & $18,5 \%$ & $-0,7 \%$ & $>$ rr industry & Healthy \\
\hline SMSM & $37,6 \%$ & $18,5 \%$ & $-19,1 \%$ & $>$ rr industry & Healthy \\
\hline
\end{tabular}

Source: Process data

Tabele 12. Results of the Profitability Ratio of Automotive Companies 2014 - 2015 2014

\begin{tabular}{|c|c|c|c|c|c|}
\hline Company Code & ROA & $\begin{array}{c}\text { Mean } \\
\text { Industry }\end{array}$ & Difference & Information & Decision \\
\hline ASII & $16,4 \%$ & $19 \%$ & $2,6 \%$ & $<$ rr industry & Unhealthy \\
\hline AUTO & $12,2 \%$ & $19 \%$ & $6,8 \%$ & $<$ rr industry & Unhealthy \\
\hline BRAM & $11,3 \%$ & $19 \%$ & $7,7 \%$ & $<$ rr industry & Unhealthy \\
\hline INDS & $14,0 \%$ & $19 \%$ & $5 \%$ & $<$ rr industry & Unhealthy \\
\hline NIPS & $15,0 \%$ & $19 \%$ & $4 \%$ & $<$ rr industry & Unhealthy \\
\hline SMSM & $44,9 \%$ & $19 \%$ & $-25,9 \%$ & $>$ rr industry & Healthy \\
\hline \multicolumn{6}{|c|}{2015} \\
\hline ASII & $15,0 \%$ & $16,2 \%$ & $1,2 \%$ & $<$ rr industry & Unhealthy \\
\hline AUTO & $12,1 \%$ & $16,2 \%$ & $4,1 \%$ & $<$ rr industry & Unhealthy \\
\hline BRAM & $12,1 \%$ & $16,2 \%$ & $4,1 \%$ & $<$ rr industry & Unhealthy \\
\hline INDS & $7,2 \%$ & $16,2 \%$ & $9 \%$ & $<$ rr industry & Unhealthy \\
\hline NIPS & $11,8 \%$ & $16,2 \%$ & $4,4 \%$ & $<$ rr industry & Unhealthy \\
\hline SMSM & $39,2 \%$ & $16,2 \%$ & $-23 \%$ & $>$ rr industry & Healthy \\
\hline
\end{tabular}

Source: Process data

Return on Asset (ROA) The average automotive company industry in Indonesia has fluctuated and decreased at the end of 2015 with an average value of $16.2 \%$ of the 
industry average value of $19 \%$ in 2014. The following results show that in the 2012 2015 period, many companies are included in the unhealthy category because the ratio of the company is below the industry average. Companies that fall into the healthy category are only PT. Nipress in 2012 - 2013 while in 2014 - 2015 PT. Nipress is also in the unhealthy category. Companies that remain in the healthy category are only PT. Selamat Sempurna in 2012 - 2015, while other companies were in the unhealthy category from 2012-2015. These results are in line with the research $[17,18]$ explaining that Profitability means the ability to make profits from all business activities of an organization, company, firm, or company. It shows how efficient management can generate profits by using all the resources available in the market

\section{Discussion}

The results of the time series analysis show that the Total Assets Turn Over of automotive companies in 2012 - 2015 shows that several companies are able to increase their ability to use total assets and maximize them in generating company profits. While overall, the total asset turnover of automotive companies is in unhealthy condition, because the average asset turnover in 2012 - 2015 the company is still below the required optimal value $(2 \mathrm{x})$. This means that there are still many companies that cannot optimize their total assets to generate maximum operating profit.

The results on Net Profit Margin show that in 2012 - 2015, the Selamat Sempurna company was able to get net profit from year to year, showing good performance so that it was able to increase the company's net profit, while other companies experienced a decline until 2015. Overall automotive companies in Indonesia also experienced a decrease in the net profit margin and was below the required critical value or limit of $5 \%$. This means that automotive companies in Indonesia have not been efficient in generating company net profits, as well as a result of a decrease in interest income held by the company. The results of the calculation of the current ratio, show the results of the liquidity ratio of automotive companies in 2012-2015 which on average decreased. The increase only occurred in a few companies in certain periods and most companies experienced a decline and the overall current ratio of automotive companies in Indonesia was not healthy because it was below $2 \%$ or the minimum required value.

The result of the overall leverage ratio of automotive companies in 2012-2015 has decreased. From year to year during the period 2012 - 2015, many companies succeeded in reducing the debt to assets ratio. Automotive companies are able to maximize the use of their assets to cover long-term debts that exist in the company and overall, automotive companies in Indonesia are in a healthy condition because the leverage ratio of automotive companies in Indonesia has moved away from the specified limit or condition, which is $100 \%$. This result is in accordance with the statement by Permatasari and Mukaram [19, 20]. 
The results of the cross-section analysis show that in 2012 - 2015 the automotive companies listed on the Indonesia Stock Exchange (IDX) were included in the unhealthy category as many as four companies, namely PT. Astra Otoparts, PT. Indo Kordsa, PT. Indospring, PT. Astra International and PT. Nipress was only in 2014 2015. While companies that were included in the healthy category from $2012-2015$ were only PT. Congratulations Perfect while PT. Nipress was included in the healthy category only in $2012-2013$. This result is made clear by the statement [21, 22] who state that the condition of the automotive industry in Indonesia is in an unhealthy state. This is internally caused by the decline in the company's net profit and many assets in the company that are still unable to optimize profit growth within the company.

Externally, the cause of the unhealthy automotive financial performance was the weakening global economy, which resulted in a decline in the automotive market share in Indonesia from early 2013 to the end of 2015, which fell to 7\%. The weakening of the automotive industry in Indonesia also resulted in the cessation of the FMI (Ford Motor Indonesia) in the automotive competition in Indonesia. The results of this study are different from the results of research conducted [23], which state that the condition of the automotive industry in Indonesia is in good or healthy condition. The difference in the results of this study occurred due to differences in time series taking in the sample data. [24] conducted research with data collection from 2006 - 2008, at which time the condition of the automotive industry in Indonesia was experiencing a significant increase. This is different from the situation in 2012 - 2015, where the weak global economy was one of the factors that had an impact on the weakness of the automotive industry in Indonesia. The phenomenon that can be revealed from this study is that in general the performance of automotive companies from $2012-2015$ by cross section analysis experienced a decline and was declared unhealthy because the current ratio, asset turnover, debt ratio and ROA, the company was less than the industry average.

\section{CONCLUSION}

Automotive companies in Indonesia in 2012 - 2015 were in an unhealthy condition due to the weakening of the global economy that occurred during 2013-2015, this is indicated by the value of the current ratio, total asset turnover, debt ratio and Return on Assets that were smaller than the average automotive industry every year during 2012 - 2015. Overall, automotive companies in Indonesia in the 2012 - 2015 period experienced a decline (unhealthy conditions) in total asset turnover, net profit margin, and current ratio. As for the debt to assets ratio, automotive companies performed quite well.

\section{REFERENCES}

[1] Bloomental, A. (2020). Financial Ratios: Ratio Analysis. Retrieved March 15, 2020, from From Investopedia: website: https://www.investopedia.com/terms/r/ratioanalysis.asp 
International Journal Of Science, Technology \& Management

[2] Haryanti, C. S. (2015). Analisis Perbandingan Laporan Keuangan untuk Menilai Kinerja Keuangan Pada Perusahaan Telekomunikasi (Studi Kasus BEI). Jurnal Ilmiah UNTAG, 4(2), 52-86. https://doi.org/http://u.lipi.go.id/1346221190

[3] Keown, A. J. (2010). Basic Financial Management (2nd ed.). Jakarta: Salemba Empat.

[4] Erni, A. (2016). Financial Ratio Analysis for Financial Performance Assessment at PT. Indofarma (Persero) Tbk (Based on Decree of the Minister of SOE Nomber: KEP100/MBU/2002). Ejournal Ilmu Adminstrasi Bisnis, 4(1), 103-115.

15] Nugroho, M. (2018). Financial Ratio Analysis that Distinguishes Company Shares Indexed in LQ45 and the Non-LQ45 on the Indonesia Stock Exchange (Bursa Efek Indonesia). Archives of Business Research, 6(11), 1-17. https://doi.org/10.14738/abr.611.5733.

[6] Rahayuningtyas, S.S \& Handayani, S. R. (2014). Pengaruh Rasio-Rasio Keuangan terhadap Dividend Payout Ratio (DPR) (Studi Pada Perusahaan Yang Listing Di BEI Tahun 2009 - 2011. Jurnal Administrasi Bisnis (JAB).

[7] Husnan, S \& Enny, P. (2015). Dasar-Dasar Manajemen Keuangan (7th ed.). Yogyakarta: UPP STIM YKPN.

[8] Houston, B. (2010). Dasar-dasar Manajemen Keuangan (1st ed.). Jakarta: Salemba Empat.

[9] Horne, J.C.V \& John, M. W. J. (2012). Prinsip-prinsip Manajemen Keuangan (13th ed.). Jakarta: Salemba Empat.

[10] Kasmir. (2012). Analisis Laporan Keuangan (6th ed.). Jakarta: PT. Raja Grafindo.

[11] Abdul, H. (2010). Manajemen Keuangan Bisnis. Bogor: Ghalia Indonesia.

[12] Sugiyono. (2017). Metode Penelitian Kuantitatif, Kualitatif dan R\&D. Bandung: Penerbit Alfa Beta.

[13] Lukman, S. (2011). Manajemen Keuangan Perusahaan (Baru). Jakarta: PT. Raja Grafindo Persada.

[14] Sampeallo, Y.G., Fariyanti \& Hidaya, N. (2020). Kinerja Keuangan dengan Pendekatan Financial Ratio dan MArket Ration pada PT Astra International Tbk. Periode 2014-2019. Jurusan Akuntansi Politeknik Negeri Samarinda, 16(2), 27-39.

[15] Sartono, S. (2015). ManajemenKeuangan: Teori dan Aplikasi (4th ed.). Yogyakarta: BPFE.

[16] Fajri1, F \& Fauziah, F. (2020). Pengaruh Rasio Profitabilitas dan DER Terhadap Harga Saham Pada Perusahaan Manufaktur Subsektor Otomotif dan Komponen. Borneo Student Research, 1(2), 920-926.

[17] Prasetya, S. G \& Nazila, R. (2019). Effect of Capital Structure and financial Performance Upon Company value of Automotive and Components Industrial Subsectors which are Registered in BEI. The Accounting Journal of BINANIAGA, 4(1), 37-47. https://doi.org/http://dx.doi.org/10.22271/allresearch

[18] Malik, A. D \& Handono, W. A. (2019). Financial Performance Analysis of Soe And Foreign Capital Cement Companies In Indonesia. International Journal of Social Sciences, 5(1), 267-294. https://doi.org/10.20319/pijss.2019.51.267294

[19] Permatasari, S.S \& Mukaram, M. (2019). Pengaruh Rasio Keuangan Terhadap Harga Saham Industri Otomotif dan Komponen di Bursa Efek Indonesia. Jurnal Riset Bisnis Dan Investasi, 5(2), 10-20. https://doi.org/10.35697/jrbi.v5i2.1623

[20] Sujata, N.K.A.P \& Badja, I. B. (2020). Rasio Pasar, Profitabilitas dan Likuiditas http://ijstm.inarah.co.id 
Berpengaruh terhadap Harga Saham Pada Perusahaan Otomotif dan Komponen. E-Jurnal Manajemen, 9(6), 2167-2186. https://doi.org/10.24843/EJMUNUD.2020.v09.i06.p06

[21] Fitri, R \& Syamwil, S. (2020). Pengaruh Likuiditas, Aktivitas, Profitabilitas dan Leverage Terhadap Financial Distress (Studi Kasus pada Perusahaan Manufaktur yang Terdaftar di Bursa Efek Indonesia Periode 2014-2018). Jurnal Ecogen, 3(1), 134-143. https://doi.org/dx.doi.org/10.24036/jmpe.v3i1.8532

[22] Agustini, N.W \& Wirawati, N. G. P. (2019). Pengaruh Rasio Keuangan Pada Financial Distress Perusahaan Ritel Yang Terdaftar di Bursa Efek Indonesia (BEI). E-Jurnal Akuntansi, 26(1), 251-280. https://doi.org/10.24843/EJA.2019.v26.i01.p10

[23] Simanjutak, C., Titik, F \& Aminah, W. (2017). The Influence of Financial Ratio to Financial Distress (Study in Transportation Companies on Listed in Indonesia Stock Exchange During 2011-2015). E-Proceeding of Management, 4(2), 1580-1587.

[24] Mubarok, R \& Dewi, F. R. (2010). Analisis Kinerja Keuangan Perusahaan dengan Metode Economic Value Added (EVA) (Studi Kasus Perusahaan Otomotif Go Publik). Jurnal Manajemen Dan Organisasi, 1(2), 107-117. 